\title{
PENGARUH JENIS PELARUT DALAM EKSTRAKSI DAUN KELOR (Moringa oleifera) TERHADAP DAYA MORTALITAS LARVA (Aedes aegypti)
}

\author{
Tiara Larasati, , Ratna Mustika Yassi, Eko Malis \\ Program Studi Kimia, Fakultas Matematika dan Ilmu Pengetahuan Alam \\ Universitas PGRI Banyuwangi \\ Email korespondensi*: tiaralarasati@gmail.com
}

\begin{abstract}
ABSTRAK
Aedes aegypti termasuk vektor dari penyakit serius seperti malaria, , demam dengue, demam berdarah dengue, filariasis, dan arbovirus yang menyebabkan masalah cukup besar. Tindakan pencegahan dari timbulnya penyakit ini salah satunya dengan memberantas sarang nyamuk dan membunuh nyamuk dewasa dengan larvasida sintetis. Ddun kelor merupakan salah satu tanaman yang memiliki fungsi larvasida. Penelitian ini bertujuan untuk mengidentifikasi kandungan senyawa alami daun kelor(Moringa oleifera) pada mortalitas larva Aedes aegypti dan mengetahui pelarut yang optimum terhadap ekstraksi daun kelor (Moringa oleifera) pada mortalitas larva Aedes aegypti.

Ekstraksi dengan menggunakan metode maserasi dengan mengambil kandungan senyawa fenolik yang terdapat pada daun kelor (Moringa oleifera), dengan menggunakan pelarut etanol, metanol, etil asetat, n-heksan, dan aquadest. Selanjutnya dilakukan uji fitokimia dan uji kuantitatif menggunakan Spektroskopi UV-Vis pada kandungan esktrak daun kelor.

Ekstrak yang paling banyak terfiltrat/ ekstraksi sebanyak $190 \mathrm{ml}$ perolehan ekstraksi etanol dan metanol, sedangkan pada etil asetat dan n-heksan $165 \mathrm{ml}$ lalu pada aquades 145 ml.Pada uji kualitatif fitokimia alur pengujian dilakukan mulai dari uji flavonoid dengan penambahan $\mathrm{NaOH} 10 \%$ dan membentuk jingga. pada uji alkaloid menggunakan preaksi Mayer terjadi endapan putih-bening dan pada Dragondorf hingga timbul warna jingga terang. Uji tanin menggunakan $\mathrm{FeCl}_{3}$ 1\% dengan hasil positif terdeteksi warna biru gelap-hitam, semua ekstrak menunjukkan hasil yang positif dalam uji ini.Data UV-VIS memberikan signal pada flavonoid terbanyak diperoleh oleh etil asetat 5,6\% dan pada metanol 3,4\%. Kadar tanin pada aquadest sebagai blanko sebesar $1,34 \%$, dan terbesar pada bagian etanol mencapai $1,06 \%$. Pemakaian ekstraksi dalam pengamatan mortalitas hidup larva memberikan hasil positif terbanyak pada ekstrak etanol, metanol, dan aquadest dengan data kematian sebesar masing- masing 6-8 ekor sedangkan pada etil asetat dan n- heksan masing-masing 1 ekor setiap counter larva. Pengamatan cukup baik dilakukan dengan efek kematian larva terhadap ekstrak.
\end{abstract}

Kata Kunci: Daun kelor (Moringa oleifera), Pelarut, UV-VIS, Aedes aegypti 


\section{PENDAHULUAN}

Berbagai upaya dilakukan untuk menekan peningkatan penderita DBD di Indonesia. Tindakan pencegahan dari timbulnya penyakit ini salah satunya dengan memberantas sarang nyamuk dan membunuh nyamuk dewasa. Tindakan membunuh nyamuk dewasa tidak efisien sehingga lebih dianjurkan untuk membunuh larva nyamuk dengan larvasida atau mencegah cucukan (Poorwosudarmo, 1993, hal. 24).Pada tahun 2014 sampai pertengahan bulan desember tercatat penderita DBD di 34 provinsi di Indonesia sebanyak 71.668 orang, dan 641 diantaranya meninggal dunia. Angka tersebut lebih rendah dibandingkan tahun sebelumnya, yakni tahun 2013 dengan jumlah penderita sebanyak 112.511 orang dan jumlah kasus meninggal sebanyak 871 penderita (Depkes, 2005).Penggunaan larvasida merupakan cara yang paling umum digunakan oleh masyarakat untuk mengendalikan pertumbuhan vektor tersebut (Aradilla, 2009). Larvasida yang sering ditemui di lapangan adalah abate (bahan aktif temefos 1\%). Pada tahun 1980, temefos $1 \%$ (abate) ditetapkan sebagai bagian dari program pemberantasan massal aedes aegypti di Indonesia (Daniel, 2008). Pada sumber lain menyatakan resistensi larva Aedes aegypti terhadap temefos sudah ditemukan dibeberapa negara, seperti Brazil, Bolivia, Argentina, Kuba, French Polynesia, Karibia, dan Thailand. Berdasarkan hal tersebut, dibutuhkan suatu inovasi untuk menggunakan bahan alternatif yang dapat digunakan sebagai larvasida dan juga ramah lingkungan. Bahan aktif tersebut bisa didapatkan dari tumbuhan yang berisi berbagai fitokimia bioaktif berpotensi sebagai larvasida (Aradilla, 2009).Salah satu tanaman yang memiliki fungsi biolarvasida adalah kelor.Seluruh bagian dari tanaman kelor dapat dimanfaatkan sebagai bahan pangan maupun obat-obatan.

Kelor dengan nama latin (Moringa oleifera )awalnya banyak tumbuh di India, namun kini kelor banyak ditemukan di daerah beriklim tropis. Pada beberapa Negara kelor dikenal dengan sebutan benzolive, drumstick tree, kelor, marango, mlonge, mulangay, nebeday, sajihan, dan sajna (Fahey,2005).Budidaya daun kelor di dunia internasional merupakan program yang sedang digalakan. Terdapat beberapa julukan untuk pohon kelor, diantaranya The Miracle Tree, Tree for Life, dan Amazing Tree. Julukan tersebut muncul karena bagian pohonkelor mulai dari daun, buah, biji, bunga, kulit batang, hingga akar memiliki manfaat yang luar biasa.

Daun kelor mengandung berbagai zat 
kimia yang bermanfaat. Fitokimia dalam

kelor adalah tannin, steroid dan triterpenoid, flavonoid, saponin, antarquinon, dan alkaloid, dimana kelor mempunyai aktivitas menetralkan radikal bebas sehingga mencegah kerusakan oksidatif pada sebagian besar biomolekul dan menghasilkan proteksi terhadap kerusakan oksidatif secara signifikan (Sreelatha,

2009).Terutamadaunnyakelor(MoringaOl eifera) yang paling tinggimengandungantioksidandibandingk anbagian-bagianlainnya.

Flavonoid adalah suatu kelompok senyawa fenol terbesar yang ditemukan di alam.Alkaloid adalah sebuah golongan senyawa basa bernitrogen yang kebanyakan heterosiklik dan terdapat di tetumbuhan (tetapi ini tidak mengecualikan senyawa yang berasal dari hewan). Asam amino, peptida, protein,nukleotid, asam nukleik, gula amino dan antibiotik biasanya tidak digolongkan sebagai alkaloid. Dan dengan prinsip yang sama, senyawa netral yang secara biogenetik berhubungan dengan alkaloid termasuk digolongan ini (Hersipa, 2011).Alkaloid sesungguhnya adalah racun, senyawa tersebut menunjukkan aktivitas phisiologi yang luas, hampir tanpa terkecuali bersifat basa; lazim mengandung Nitrogen dalam semuanya merupakan antioksidan (Kasolo J,N, 2010). Antioksidan didalam daun

cincin heterosiklik. Tanin adalah senyawa metabolit sekunder yang terdapat pada beberapa tanaman. Tanin mampu mengikat protein, sehingga protein pada tanaman dapat resisten terhadap degradasi oleh enzim protease di dalam silo ataupun rumen (Kondoet al., 2004).Saponin adalah senyawa aktif permukaan yang kuat dan menimbulkan busa bila dikocok dengan air. Beberapa saponin bekerja sebagai antimikroba. Dikenal juga jenis saponin yaitu glikosida triterpenoid dan glikosida struktur steroid tertentu yang mempunyai rantai spirotekal. Kedua saponin ini larut dalam air dan etanol, tetapi tidak larut dalam eter. Aglikonya disebut sapogenin, diperoleh dengan hidrolisis dalam suasana asam atau hidrolisis memakai enzim (Robinson, 1991).

Ekstrak merupakan sediaan pekat yang diperoleh dengan menarik zat aktif dari simplisia nabati atau simplisia hewani menggunakan pelarut yang sesuai. Metode penarikan zat aktif ini berupa pemisahan senyawa di mana komponen-komponen terlarut dari suatu campuran dipisah dari komponen yang tidak larut dengan pelarut sesuai, sedangkan proses perpindahan massa zat 
aktif yang semula berada dalam sel yang ditarik oleh cairan penyari sehingga didapatkan zat aktif larut dalam penyari disebut dengan penyarian. Pembuatan ekstrak dimaksudkan agar zat berkhasiat yang terdapat di dalam simplisia terdapat dalam bentuk yang mempunyai kadar yang tinggi dan hal ini memudahkan zat berkhasiat tersebut dapat diatur dosisnya.Metode maserasi merupakan penyarian sederhana yang dilakukan dengan cara merendam sejumlah serbuk simplisia dalam larutan penyari yang sesuai selama beberapa hari dalam temperatur kamar dan terlindung cahaya. Maserasi digunakan untuk menyari simplisia dengan komponen kimia yang mudah larut dalam cairan penyari (Kristiani \& Halim, 2014, hal. 1418).Skrining fitokimia adalah tahap pendahuluan dalam suatu penelitian fitokimia yang bertujuan untuk memberikan gambaran tentang golongansenyawa yang terkandung dalam tanaman yang sedang diteliti. Metode skrining fitokimia dilakukan dengan melihat reaksi pengujian warna dengan menggunakan suatu pereaksi warna. Hal penting yang berperan penting dalam skrining fitokimia pemilihan pelarut dan metode ekstraksi (Kristanti, 2008).Spektrofotometer adalah alat yang digunakan untuk menganalisa suatu senyawa baik kuantitatif maupun kualitatif, dengan cara mengukur transmitan ataupun absorban suatu cuplikan sebagai fungsi dari konsentrasi.

Aedes aegypti Salah satu nyamuk yang merupakan vektor dari berbagai macam penyakit, adalah Aedes aegypti. Taksonomi Aedes aegypti Adalah sebagai berikut (Sudarto, 1972). Nyamuk Aedes aegypti mula-mula banyak ditemukan di kota-kota pelabuhan dan dataran rendah, kemudian menyebar ke pedalaman. Penyebaran nyamuk Aedes aegypti terutama dengan bantuan manusia, mengingat jarak terbang rata-rata yang tidak terlalu jauh, yaitu sekitar $40-100$ meter. Meskipun jarak terbang Aedes aegypti bisa mencapai $2 \mathrm{~km}$ namun jarang sekali terbang sampai sejauh itu karena tiga hal penting yang dibutuhkan untuk berkembang biak terdapat dalam satu rumah, yaitu tempat perindukan, tempat mendapatkan darah, dan tempat istirahat (Sudarto, 1972).Siklus hidup nyamuk Aedes aegypti secara sempurna yaitu melalui 4 empat stadium, yaitu telur, larva, pupa, dan dewasa (Sudarto, 1972; Aradilla, 2009).

Pengunaanbahankimia yang seringdipakaiadalahinsektisida, Insektisida adalah suatu bahan yang mengandung persenyawaan kimia digunakan untuk memberantas dan mengendalikan serangga (Soedarto, 2011).World Health Organization (WHO) 
mengklasifikasikan pestisida atas dasar toksisitas dalam bentuk formulasi padat dan cair (WHO,1993). Kelas IA(amat sangat berbahaya), Kelas IB(amat berbahaya), Kelas II (cukup berbahaya), Kelas III (agak berbahaya). Penggunaan pestisida sintetis di seluruh dunia selalu meningkat dan penggunaan pestisida campuran juga sangat banyak ditemukan diareal pertanian. Berdasarkan toksisitas dan golongan, pestisida organik sintetik dapat digolongkan menjadi Organofosfat, Karbamat, Organoklorin. Adapun senyawa yang paling efektif untuk membunuh larva Aedesaegypty adalah Abate(Temefos 1\%), namun pengunaan Abate banyak berdampak negative seperti resistensi terhadap pemakaian dan saat berkontak dengan manusia. Abate dapat mengakibatkan keracunan yang membuat sakit kepala, iritasi, dan hilang ingatan. Selain itu, Abate juga sangat beracun bagi beberapa hewan air.

Insektisida nabati diartikan sebagai bahan kimia beracun yang secara alami diekstrak dari tanaman, Insektisida ini juga dikenal sebagai insektisida alami (natural occuring insecticides).

\section{Metodologi}

\subsection{Alat dan Bahan}

\section{Alat}

Dalam penelitian

ini
Insektisida nabati berasal dari senyawa hasil metabolisme sekunder tumbuhan dengan aktivitas biologis tertentu. Kardinan dalam (Naria, 2005) menyebutkan senyawa longan sianida, saponin, tanin, flavonoid, alkaloid, steroid, dan minyak atsiri adalah senyawa dalam tumbuhan yang dapat berfungsi sebagai insektisida.Apabila insektisida ini diaplikasikan akan membunuh organisme sasaran dan residunya cepat hilang,sehingga tidak mencemari lingkungan dan relatif aman bagi organisme bukan sasaran (Naria, 2005).

Penelitian dilakukan untuk mengetahuipengaruhjenispelarutanEkstra sidaunkelor(MoringaOliefera)

terhadapdayamortalitas larva (AedesAegypty).pelaruttersebutadalahestr aketanol $70 \%$, methanol, etilasetat, $\mathrm{n}$ heksana dan aquadest. Pada penelitan ini, yang akan diamati antara lain adlah ratarata mortalitas larva Aedes Aegypty, Hasi optimasil yang diperoleh dari proses ekstraksi digunakan sebagai Insektisida alami untu kmembunuh larva nyamuk (AedesAegypty) terhadap ekstrak.

mempergunakan antara lain neraca analitik, pipet tetes, gelas ukur $100 \mathrm{ml}$, corong pemisah, erlenmeyer, papan plat tetes porselen, nampan plastik, loyang 
aluminium, 15 wadah plastik (sebagai kontainer), beker glass, kain (sebagai pelindung agar nyamuk dewasa tidak terbang keluar), blender atau juicer, batang pengaduk kaca, ekstraktor (peralatan maserasi), kertas saring whatman no 1 , kertas label, pisau, labu takar $50 \mathrm{ml}$, pipet volume, sarung tangan, beaker glass, cawan porselen, jam (penghitung waktu).

\section{Bahan}

Dalam penelitian ini mempergunakan antara lain ekstrak etanol 70\%, metanol, etil asetat, n-heksana, dan aquadest (teknis) pada daun kelor; $\mathrm{NaOH} 10 \%$ (uji flavonoid), pereaksi Mayer, pereaksi Dragendorf (uji alkaloid), $\mathrm{FeCl} 3$ 1\% (uji tanin), larva Aedes aegypti instar III; fish food untuk makanan larva.

\subsection{Metode Penelitian}

\subsubsection{Tahap Pembuatan Ekstrak}

\section{Kasar Daun Kelor}

$\begin{array}{lrrr}\text { Daun kelor } & \text { segar } \rightarrow & \text { Dipisahkan } \\ \text { bagian daun } & \text { dan } & \text { batang } \\ \text { Diangin } \rightarrow \text { anginkan } & \text { dalam } & \text { loyang } \rightarrow \\ \text { Pengovenan } & 70-80 \circ C \text { selama } \pm 2 \text { jam. }\end{array}$

\subsubsection{Tahap Maserasi}

Penyerbukan (blender), lalu penimbangan ekstrak kasar sebanyak masing-masing $10 \mathrm{~g} \rightarrow$ Menyiapkan pelarut sebanyak $200 \mathrm{ml}$ pada setiap variasinya $\rightarrow$ Melakukan proses maserasi dengan rasio 1:20 dengan kurun waktu 3 x 24 jam.

\subsubsection{Uji Fotokimia}

\section{Uji Flavonoid}

Hasil ekstraksi $\rightarrow$ Teteskan pada plat tetes $\rightarrow$ Tambahkan $\mathrm{NaOh} 10 \%$, positif bila larutan mengendap jinggga.

\section{Uji Alkaloid}

Hasil ekstraksi $\rightarrow$ Tambahkan pada papan plat, beri pereaksi Mayer dan Dragodorf $\rightarrow$ Hasil positif akan membentuk endapan putih (Mayer) dan jingga terang-coklat pada (Dragondorf).

\section{Uji Tanin}

Hasil ekstraksi $\rightarrow$ Tambahkan pada papan plat, beri tetesan larutan $\mathrm{FeCl} 3$ $1 \% \rightarrow$ Hasil positif akan memebentuk warna kebiruan hingga hitam.

\subsubsection{TeknikAnalisis Data}

A. Kadar air = berat sampel awal basah - berat sempel akhir kering

B. Rata-rata kematian larva = $\underline{\text { jumlah angka kematian terbesar }}$

$$
\text { jumlah pengulangan }
$$

\section{Hasil dan Pembahasan}

\section{Pembahasan}

Komponen yang terkandung dalam daun kelor (Moringa oleifera) diantaranya flavonoid, alkaloid, dan tanin dan masih banyak zat kimia lainnya. Penelitian ini 
berdasarkan literatur yang membahas biolarvasida alami dengan pengaruh komponen zat dalam bahan utama. Komponen zat yang mempengaruhi dalam biolarvasida alami adalah senyawa-senyawa bioaktif dan fenolik seperti diatas

Proses ekstraksi peneliti menggunakan metode maserasi yang dilakukan selama 3x24 jam. Bahan utama daun akan diperoleh ekstrak kasar yang akan diproses dengan melakukan maserasi. Pada akhir proses maserasi filtrat akan dipisahkan dengan residunya menggunakan corong dan kertas saring Whatmaan no 1. Filtrat/ ekstrak yang dihasilkan pada masing-masing pelarut tentu berbeda, hal ini disebabkan karena pengaruh kepolaran dalam pelarut yang digunakan dan senyawa yang terkandung dalam daun kelor. Dalam proses maserasi pembagian rasio 1:20 dimaksudkan dengan menimbang 10 gram masingmasing ekstrak kasar yang di dapat lalu dilarutkan dalam $200 \mathrm{ml}$ pelarut yang tersedia. Berdasarkan keterangan diatas senyawa-senyaa dalam daun kelor cukup tertarik dalam basis pelarut yang digunakan. Sesuai dengan metode dasar maserasi merupakan proses penarikan suatu senyawa pada bahan aktif yang diuji melalui pelarut yang telah ditentukan. Berbagai macam senyawa yang terkandung dalam daun kelor (Moringa oleifera) hanya senyawa fenolik (alkaloid, flavonoid, dan tanin) yang fokus diteliti dalam penelitian ini. Senyawa tersebut berkaitan dengan pengaruh daya biolarvasida yang akan dikembangkan lebih lanjut. Pada penelitian biolarvasida kelor dalam bagian daunnya belum terverifikasi sebagai bahan yang dapat diuji sebagai biolarvasida alami, maka dalam penelitian kali ini merupakan penelitian pendahuluan sebagai asas dasar pemikiran awal.

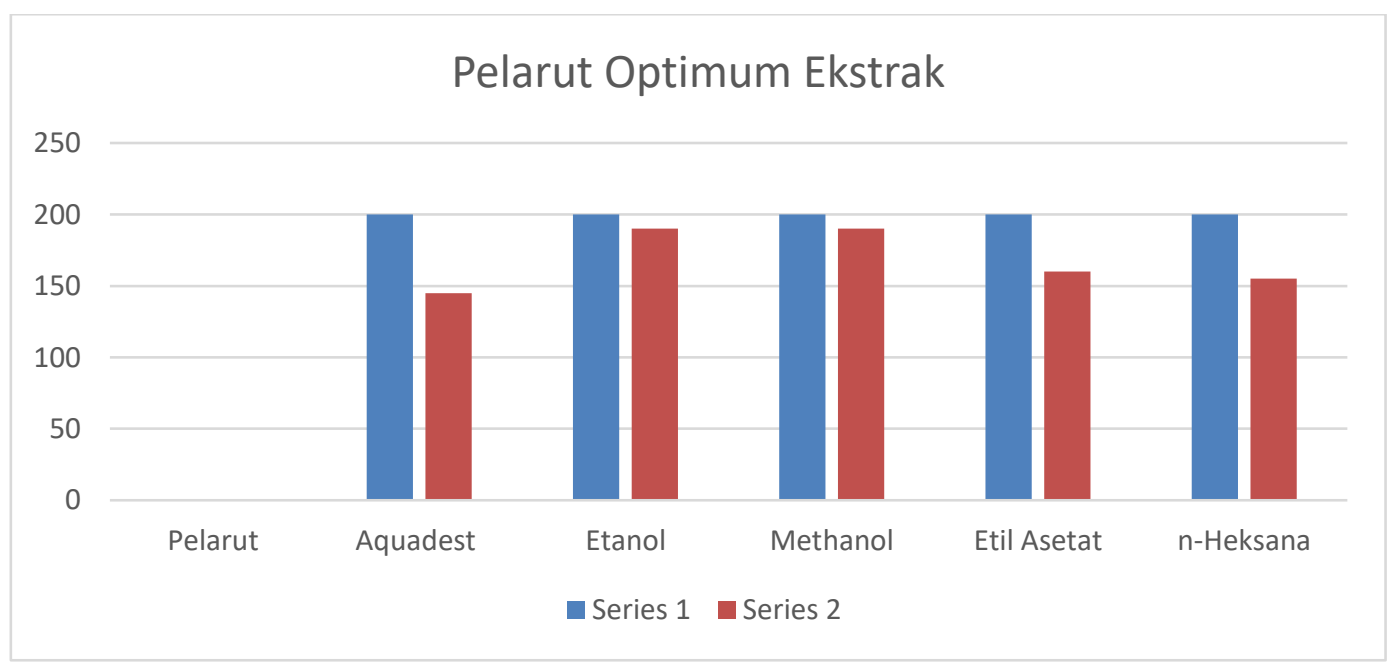


Berdasarkan data pengamatan kualitatif (grafik di atas )mendapatkan hasil data pelarut yang optimum etanol dan methanol dengan mencapai batas filtrat utama $190 \mathrm{ml}$ sedangkan ethil asetat dan n-hexan memperoleh $165 \mathrm{ml}$, pada aquades lebih sedikit perolehannya sebanyak $145 \mathrm{ml}$. Pemakaian variasi pelarut dalam uji ini memberikan refrensi sebagai acuan pengambilan data yang paling optimum dalam mengekstrak senyawa yang terkandung di dalam daun kelor (Moringa oleifera). Etanol dan metanol paling banyak mengekstrak karena senyawa tersebut termasuk senyawa yang lebih polar dari pada etil asetat dan n-heksan. Kepolaran senyawa tersebut akan menarik beberapa kandungan bioaktif yang terdapat pada daun kelor. Senyawa bioaktif yang diinginkan terbawa dalam proses ini adalah aenyawa flavonoid, alkaloid, dan tanin sebagai tujuan uatamanya. Aquadest termasuk dalam deretan kepolaran yang sangat polar, namun dalam proses maserasi aquades dan ekstrak kasar membentuk reaksi pembusukan yang mengakibatkan filtrat yang didapat tidak tersaring dengan baik. Hal ini terjadi karena bagian pembusukan berada di leher wadah yang yang terpisah dengan bagian kental (filtrat) dan menghalangi keluarnya filtrat yang didapat. Dan pembusukan mungkin terjadi karena banyaknya mikroorganisme yang masuk dalam wadah sehingga lebih cepat membusuk dibanding dengan lainnya. Maka dari itu filtrat yang di peroleh hanya $145 \mathrm{ml}$ lebih sedikit.

$$
\text { Pengujian yang dilakukan }
$$

berdasarkan uji kualitatif, kuantitatif dan uji mortalitas larva. Pada uji kualitatif menggunakan metode Skrining fitokimia dan pada kuantitatif mengidentifikasi senyawa menggunakan alat spektrofotometer UV-VIS pada lab CDAST Jember. Skrining fitokimia adalahpemeriksaan komponen kimia secara kualitatif untuk mengetahui golongan senyawa yang terkandung dalam suatu tumbuhan.Pemeriksaan dilakukan pada senyawa fenolik yang memiliki khasiat biolarvasida alami seperti alkaloid, flavonoid, dan tanin. Pada uji di penelitian ini yang pertama yaitu flavonoid, selanjutnya uji alkaloid dan terakhir tanin.

Uji flavonoid dengan penambahan $\mathrm{NaOH} 10 \%$ pada masing-masing plat tetes pengamatan. Bila terpositif flavonoid warna akan berubah menjadi kekuningan, jingga samapi kemerahan. Flavonoid merupakan pigmen yang paling sering banyak di temukan pada tumbuhan mulai dari fungus sampai angiospermae. Pada tumbuhan tingkat tinggi flavonoid baik ditemukan pada bagian negative maupun bunga flavonoid 
merupakan senyawa fenolik yang bersifat fenol. Senyawa fenol yang akan bereaksi dengan $\mathrm{NaOH} 10 \%$ akan membentuk garam natrium fenolat. Fenol memiliki gugus $-\mathrm{OH}$ dalam benzenya, saat ikatan hidogen-oksigennya pada fenol terputus maka $\mathrm{Na}$ menggantikan posisi $\mathrm{H}$ dalam benzene dan membentuk garam natrium fenolat.

Uji Alkaloid menggunakan preaksi Mayer dan Dragondrof. Pada preaksi Mayer larutan ketika ditetesi berwarna bening atau memudar dari warna asli nya. Dilakukan dua pengamatan agar dapat membandingkan hasilnya. Alkaloid bersifat basa karena adanya pasagan elektron bebas pada atom nitrogennya mampu membentuk senyawa kompleks dan tidak larut dalam logam berat.

Hasil yang diperoleh pada pereaksi Mayer (endapan putih- kuning) untuk sampel fraksi dan kristal larutan bening yang menandakan reaksi negatif atau pereaksi meyer tidak mampu menarik senyawa alkaloid dalam sampel yang disebabkan pereaksi yang digunakan untuk menguji terlalu sedikit sehingga uji yang dihasilkan negatif. Pada tabel uji alkaloid dengan pengujian menggunakan preaksi mayer negatif. Hasil positif pada uji dengan preaksi Dragondorf pada perubahan warna sampai jingga-coklat.

Uji Tanin merupakan senyawa polifonel yang banyak terkandung dalam berbagai jenis tanaman. Untuk melakukan identifikasi tanin dalam suatu simplisia dapat dilakukan dengan berbagai metoda identifikasi. Proses indentifikasi ini bertujuan untuk mengetahui benar atau tidaknya suatu simplisia mengandung tanin. Selain itu karena tanin sangat beraneka ragam jenisnya, maka dengan proses identifikasi ini kita juga dapat meprediksi jenis tanin apakah yang dikandung dalam simplisia yang diuji.

Metode-metode yang kerap digunakan dalam proses identifikasi tanin antara lain adalah: Uji Goldbeater's skin, Uji Warna dan Pengendapan, Uji Larutan Gelatin, Identifikasi Breamer's, Identifikasi dengan Reagen Bromin, Identifikasi dengan Phenazone, Identifikasi Mitchell's, dan Uji Senyawa Katekin. Seperti senyawa fenol lainnya tanin akan bereaksi dengan garam Besi (III). Larutan sampel akan memberikan warna intesif merah, biru, unggu atau hijau, dari kompleks triaryloksi yang menandakan adanya senyawa fenol dalam sampel tersebut.

Uji Tanin yang menggunakan preaksi $\mathrm{FeCl}_{3}$ besi (III) klorida memberikan hasil positif denganwarna kehitaman yang kuat. Hal ini terjadi karea tanin yang terhidrolisa seperti gallotanin dan ellgitanin akan memberikan endapan berwarna biru.

Dalam skrining fitokimia 
mendapatkan hasil dari uji kualitatif, diantaranya dapat terdeteksi flavonoid, alkaloid, dan tanin dari beberapa pelarut yang terekstrak. Berdasarkan pengujian kualitatif terlihat bagian pelarut yang lebih polar yang mendekati deteksi positif, seperti aquadest, etanol, dan metanol. Keterangan dapat dilihat dalam tabel 2, 3, dan 4 .

Pada uji kuantitatif yang dilakukan di Lab CDAST Jember menggunakan spektrofotometri UV-VIS. Pengidentifikasian senyawa yang dilakukan hanya flavonoid dan taninnya saja

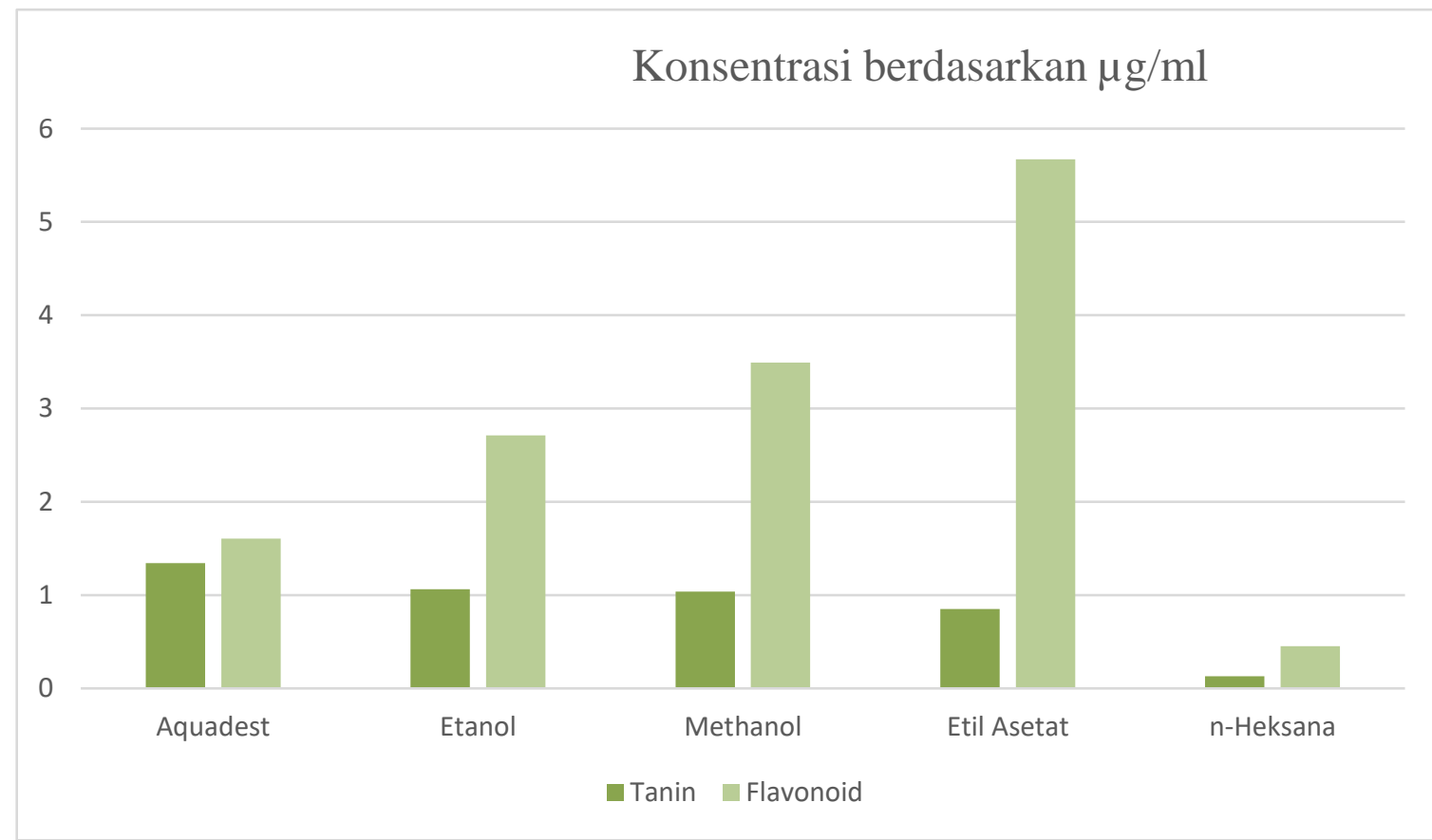

\section{Data Grafikhasil UV-VIS}

Flavonoid danTanin

Pada pengidentifikasian senyawa ekstrak alkaloid tidak termasuk di identifikasi secara kuantitatif karena minimnya bahan pendeteksi yang akan memberikan signal baik pada ekstrak. Panjang gelombang yang telahditentukan oleh lab CDAST UNEJ diantaranya pada kandungan flavonoid mulai $325 \mathrm{~nm}-510$ $\mathrm{nm}$ serta kurva standart yang digunakan quercetin dan tanin $325 \mathrm{~nm}-725 \mathrm{~nm}$ dengan menggunakan kurva standart asam galat. Perolehan hasil data yang menyatakan bahwa kandungan flavonoid pada ekstrak daun kelor $1,6 \mu \mathrm{g} / \mathrm{ml}$ pada aquadest, 2,7 $\mu \mathrm{g} / \mathrm{ml}$ pada etanol, 3,4 $\mu \mathrm{g} / \mathrm{ml}$ pada methanol, 5,6 $\mu \mathrm{g} / \mathrm{ml}$ pada ethyl asetat dan n-hexan $0,45 \mu \mathrm{g} / \mathrm{ml}$. Perolehan hasil data pada tanin lebih rendah dibanding perolehan kadar flavonoid data pertama aquadest 1,3 $\mu \mathrm{g} / \mathrm{ml}$, etanol $1,06 \mu \mathrm{g} / \mathrm{ml}$, methanol 1,03 $\mu \mathrm{g} / \mathrm{ml}$, ethyl asetat $0,8 \mu \mathrm{g} / \mathrm{ml}$ dan $\mathrm{n}$-hexan $0,1 \mu \mathrm{g} / \mathrm{ml}$.

Berdasarkan informasi di atas 
disimpulkan bahwa flavonoid lebih dominan dalam daun kelor. Namun masih banyak lagi senyawa bioaktif yang dapat terdeteksi lebih lanjut bilamana penelitian dilakukan lebih dalam lagi. Dalam penelitian ini dapat diperhatikan pada data yang muncul pada pelarut ekstraksi etil asetat dapat lebih baik mengekstrak kandungan flavonoid yang mencapai batas 5,6\%. Hal ini memungkinkan bahwa senyawa flavonoid secara baik tertarik dalam proses maserasi berlangsung. Flavonoid juga merupakan senyawa polifenol sehingga bersifat senyawa fenol, karena itu warnanya berubah bila ditambahkan basa atau amoniak. Flavonoid kurang polar seperti (isoflavones, flavones, flavones termetilasi, dan flanol) yang terekstraksi dengan chloroform, dichloromethane, diethyl ether, atau ethyl acetat, sedangkan flavonoid glycosides dan aglikon yang lebih polar terekstraksi dengan alkohoh atau campuran alkohol air.

Bagian pada daun setelah di teliti ternyata mengandung senyawa bioaktif salah satunya senyawa-senyawa fenolik. Flavonoid, alkaloid, dan tanin merupakan zat yang dapat meracuni larva Aedes aegypti instar III sehingga dapat digunakan sebagai salah satu upaya pencegahan penyakit Demamberdarah. Pada lingkungan sekitar biasanya masyarakat menggunakan Abate yang mengandung temefos $1 \%$ di dalamnya.

Kematian rata-rata pada setiap pelarut dapat dilihat dalam perhitungan bagian lampiran B. Pada blanko konsentrasi $4000 \quad-5000 \quad$ ppm mendapatkan hasil kematian hanya dengan 30 menit pertama sudah memberikan efek racun pada seluruh larva yang diamati. Hal ini dapat dipertimbangkan dalam penelitian selanjutnya.

\section{Kesimpulan}

Berdasarkan hasil penelitian dapat ditarik beberapa kesimpulan sebagai berikut:

1. Ekstrak daun kelor (Moringa oleifera) terbuki positif mengandung flavonoid, alkaloid, dan tanin. Namun yang sangat besar kandungan kimianya yaitu flavonoid dan tanin. Zat fenolik tersebut sudah mampu memberikan efek biolarvasida alami terhadap larva Aedes aegypti instar III.

2. Berdasarkan penelitian pengaruh pelarut yang digunakan dapat mengekstraksi dengan baik, hal ini di tunjukan pada data pengamatan yang menyatakan pelarut etanol, metanol mengekstrak sebanyak $190 \mathrm{ml}$. Perolehan flavonoid yang terkandung dalam ekstrak daun 
kelor( Moringa oleifera) sebesar

$5,6 \mu \mathrm{g} / \mathrm{ml}$ menggunakan pelarut ethyl asetat, dan tanin 1,06 $\mu \mathrm{g} / \mathrm{ml}$ dengan pelarut ethanol. Untuk efek kematian larva dapat disimpulkan bahwa ekstrak daun kelor dapat menjadi alternatif baru dalam bidang biolarvasida alami. Pencapaian data pengamatan mortalitas sebesar $10,3 \%$ pada penggunaan pelarut aquadest, sedangkan pada abate / Temefos $1 \%$ sebesar $13 \%$. Hal ini dapat dikatakan ekstrak dapat memberi efek racun cukup baik.

\section{Saran}

Berdasarkan hasil-hasil penelitian dapat di tarik beberapa saran sebagai berikut:Penelitian lebih lanjut terhadap pemakaian ekstrak sebagai biolarvasida alami, seperti pengujian zat bioaktif lebih banyak lagi dan kontrol positif pada mortalitas yang ditingkatkan pada waktu maupun jumlah pembiakannya.

\section{Daftar Pustaka}

Achmad, H. (1993). Materi Pokok Kimia Dasar I. Universitas Terbuka.

Achmadi. (2011). Atlas Entomologi Kedokteran. Jakarta: EGC.

Ahadi, M. R. 2003. Kandungan Tanin Terkondensasidan Laju Dekomposisi pada
Serasah Daun Rhizosporamucronatapada Ekosistem TambakTumpangsari, Purwakarta. Skripsi.Institut Pertanian Bogor, Bogor.

Amirth, Pal, Singh, 2002. A Trestie on Phytochemistry. Emedia Sience Ltd.

Anshory, I. d. (2003). Acuan Pelajaran Kimia. Jakarta: Erlangga.

Aradilla, A. S. (2009). Skripsi, Uji Efektivitas Larvasida Ekstrak Etanol daun Mimba(Azhadirachta indicia) terhadap larva Aedes aegypti. Ilmiah kedokteran , Universitas Diponegoro, Fakultas Kedokteran, Semarang, hal 11-12.

Ariningsih, K. 2004. Penambahan Sumber Tanin yang Berbeda dalam Perebusan Telur Asin terhadap Kualitas Mikrobiologi Selam Penyimpanan. Skripsi. Fakultas Peternakan. Institut Pertanian Bogor, Bogor.

Astuti, D. (2008). Upaya Pemantauan Nyamuk Aedes aegypti ,Warta, Vol.2(11), hal 90-98.

Bahang, Z. (2011). Siklus Hidup Aedes aegypti Vektor. Jakarta.

Behera, \& et.al. (2012). UV-Visible Spectrophotometric Method Development and Validation Of Assay Of Paracetamol Tablet Formulation. Journal Analytical and Bioanalytical ,Vol 3 (6), hal 1-6.

Burger,I., Burger,B,V. Albrecht,C.F. Spicies,H.S.C. and Sandor.P.,1998. Triterpenoid saponin From Bacium gradivlona Var. Obovatum Phytochemistry.Vol 49. hal 2087-2089.

Chumark, P. K. (2008). The in vitro and ex vivo antioxidant properties, hypolipidaemic and antiatheroschlerotic activities of water extract of Moringa oleifera Lam. Leaves. J. Ethnopharmacol, Vol. 90 (116), hal 439- 446.

D., C. In C. D, Intisari Kimia Farmasi Edisi Kedua. Jakarta: Penerbit Buku Kedokteran EGC.

Daniel. (2008). "Ketika Larva dan Nyamuk Dewasa Sudah Kebal Terhadap Insektisida" . Jurnal FARMACIA, Vol 7 (7), hal 114-117. 
Departemen Kesehatan Republik Indonesia, 2008, Modul: Pelatihan Bagi pelatih Pemberantasan Sarang Nyamuk (PSN) DBD Dengan Pendekatan Komunikasi Perubahan Perilaku (KPP)/Communication For Behavioral Impact (COMBI), Direktorat Jenderal Pengendalian Penyakit dan Penyehatan Lingkungan, DepkesRI, Jakarta.

Depkes, 2. R. (2005). Pencegahan dan Pemberantasan Demam Berdarah Dengue di indonesia, Jakarta: Depkes RI 2005.

Deaville, E. R.,Givens,D. I.andHarvey, I. M. 2010. Chesnut andMimosa tannin silages: Effect in sheep differ for apparent digestibilty, nitrogen utilitationand losses. Anim. Feed Sci. Technol. Vol 157: 129-138.

Duke, J. (2001). Moringa Oleifera Lam. Duke, J.A. (Ed.). Jakarta: Gramedia Pustaka Utama,Vol.2(1), hal 214-217.

Djojosumarto, P., 2008, Pestisida dan Aplikasinya, Agromedia Pustaka, Jakarta. hal 207-208.

Fahey, J. (2005). Moringa Oleifera: A Review of the Medical Evidence for Its Nutritional, Therapeutic, and Prophylactic Properties Part 1. Trees for Life, Vol 1(2), hal 5-30.

Gandahusada, Srisasi, Henry D. Illahude, dan Wita Pribadi, 2000, Parasitologi Kedokteran, Fakultas Kedokteran Universitas Indonesia, Jakarta. hal 248- 249.

Harbone, J. (1987). Penuntun Cara Modern Menganalisis Tumbuhan. Bandung: ITB, hal 123-129.

Hendratno, S. (2009). Panduan Kuliah Mahasiswa Entomologi: Diktat Kuliah Fakultas Kedokteran Universitas Diponegoro Semarang. pers.

Hesse, M. 1981. Alkaloid Chemistry. Toronto: John Wiley and Sons, Inc.

Hasibuan, R., 2012, Insektisida Pertanian, Lembaga Penelitian Universitas Lampung. hal 62.

Iskandar. (1985). Pemberantasan Serangga dan Binatang Pengganggu.Jakarta: Pusdiknes
Depkes RI.

Irawati, S., 2010, Memanfaatkan Kekayaan Flora di Daerah Tropis sebagai Alternatif Solusi untuk Menurunkan Angka Kasus DBD di IndonesiaJurnal UI Untuk Bangsa Seri Kesehatan, Sains, dan Teknologi,Vol. 1, hal. 39-49.

Jayanegara, A. \& E. Palupi. 2010. Condensed tannin effect on nitrogent digestion in ruminantia meta-analysis from invitro and invivo studies, Med. Pet. edisi 2010: hal 176181.

Kasolo J.N, B. G. (2010). Phytochemicals and Uses of Moringa Oleifera Leaves in Ugandan rural Communities. Madicinal Plant Reseacrch, Vol 4 (9), hal 753-757.

Kim Nio, Ocy.1989. Zat-zat toksik yang secara alamiah ada pada tumbuhan nabati. Cermin Dunia Kedokteran, Vol 58, hal 315330.

Khopkar. (1990). Konsep Dasar Kimia Analitik. Jakarta: Universitas Indonesia.

Kristanti, Alfinda Novi. (2008). Buku Ajar Fitokimia.Surabaya: Universitas Airlangga, hal 35-40.

Kristiani, V., \& Halim, F. I. (2014). Pengaruh Konsentrasi Etanol Dan Waktu Maserasi, . Universitas Katolik Widya Mandala:SurabayaRepository, Vol.4 (2), hal 14-18.

Kumala, N. (2016). Potensi Ekstrak Daun Kelor (Moringa oleifera)sebagai Hepatoprotektor pada Tikus Putih (Rattus Novergicus) yang Diinduksin Paracetamol Dosis Toksis. Ilmiah Kedokteran ,Vol 5 (1), hal 58-59.

Kondo, M., N. Naoki, K. Kazumi \&H. O. Yokota. 2004a . Enhanced lactic acid fermentation of silage by the addition of green tea waste. J. Sci. Food Agric. Vol 84: hal $728-734$.

Naria, E., 2005, Insektisida Nabati untuk Rumah Tangga, Universitas Sumatera Utara, Medan. hal 29.

Noshirma, M., \& willa, R. w. (2016). Larvasida Hayati yang digunakan dalam upaya pemberantasan, Universitas Kristen 
Maranantha: Bandung, hal 33-36.

Matsjeh, S. 2002. Kimia Hasil Alam Senyawa Metabolit Sekunder Tumbuhan Falvonoid, Terpenoid dan Alkaloid. Jogjakarta: Jurusan Kimia FMIPA UGM. hal 431-463.

Maldonado, R. A. P. 1994. The Chemical Nature and Biologycal Activity of Tannins in Forages Legumes Fed to Sheep and Goat. Thesis. Departement of Agriculture Australia. University of Quensland Australia, Australia.

Morrisey JP dan Ousbon AE, 1999. Fungal Resistence to Plant Antibiotic as a Mechanism of Phatogenesis. Mikrobiologi and molecular biologi. Vol 63, hal 708-729.

Poorwosudarmo. (1993). Demam Berdarah Dengue pada Anak. JAKARTA: UI press.

Rajanandh, M.G. (2012). Moringa Oleifera A Herbal Medicine:A Pre Clinical Report . Asian Pasific Journal of Tropical Disease, 2(SUPPUL2), hal 709- 795.

Robinson, T. (1991). The Organic Constituens of higher Plants. University of Massachusetts Edisi VI: Bandung, ITB, hal 191-216.

Roloff, A. H. Weisgerber, U. Lang, B. Stimm (2009). Moringa oleifera Lamk. WILEY-VCH Verlag GmbH \& Co. KGaA (1785). Vol 12(3), hal 1-8.

Sastrohamidjojo, H. (1991). Kromatografi. Kromatografi edisi II : Liberty, Yogyakarta, hal 26-36.

Sastrohamidjojo, H. (1992). Pektroskopi Inframerah Edisi I Cetakan I: Liberty, Yogyakarta, hal 13.

Susanti, C. M. E. 2000. Autokondensat tanin sebagi perekat kayu lamina. Jurusan IPK. Program pasca sarjana IPB. Bogor. Desertasi Soedarto, 2011, Buku Ajar Parasitologi Kedokteran, Sagung Seto, Jakarta, hal 318319.

Sreelatha, S. P. (2009). Antioxidant Activity and Total Phenolic Content of Moringa Oleifera Leaves in two Stage of Maturnity: Plant foods, Vol 64(3), hal 303-311.

Sudarto. (1972). Atlas Entomologi
Kedokteran. Jakarta: EGC, hal 18.

Sudjadi. (1988). Metode Pemisahan. Universitas Gadjah Mada, Fakultas Farmasi, hal 167-177.

Tippler, P. A. (1991). Fisika Untuk Sains dan Teknik, Jilid 1. Jakarta, Erlangga Jilid 1.

Underwood, A.L and R.A Day, Jr. (1986). Analisa Kimia Kuantitatif. Jakarta: Erlangga .

Yoshiki Y, Kudo \& Okobo K,1998. Relationship Between Cemical Structure and Biologica Activities of Triterpenoid Saponin from Soybean (Reviw). Biosience Biotechnology and Biochemistry. Vol 62. hal 2291-2292.

Trisna T.L (2018). PengaruhJenisPelarutDalamEkstraksiDaunKe lor (MoringaOliefera) TerhadapDayaMortalitas Larva (AedesAegypty), Skripsi. Prodi Kimia, FakultasMIPA Universitas PGRI BanywangiAgustus 2018. 